\title{
PELATIHAN MENGOLAH SAMPAH KOTAK SUSU MENJADI DOMPET DI PERKUMPULAN WANITA KATOLIK KRISTUR RAJA KECAMATAN TENGGARONG SEBERANG
}

\author{
${ }^{1}$ Theresia Tutik Ismiati \\ Program Studi DIII Keperawatan Stikes Dirgahayu Samarinda \\ Jalan Pasundan No.21 Telp (0541) 748335, Fax. (0541)748335 \\ email: theresialegowo88@gmail.com
}

\begin{abstract}
Abstrak
Salah satu faktor yang menyebabkan rusaknya lingkungan hidup adalah sampah. Selain dapat mendatangkan bencana bagi masyarakat, sampah juga dapat diubah menjadi barang yang bermanfaat. Tujuan dari kegiatan ini adalah untuk meningkatkan kesadaran, aktifitas dan kreatifitas masyarakat dalam pengolaan limbah dan barang bekas. Pelatihan ini diikuti oleh 20 peserta yang merupakan perkumpula wanita katolik kristus raja kecamatan tenggarong seberang. Kegiatan ini dilakukan sebanyak delapan kali pertemuan. Peserta pelatihan dipersilahkan mengembangkan ide dan kreativitasnya. Hasil kegiatan ini menunjukkan kreatifitas dan antusias peserta pelatihan dengan baik. Hasil karya yang telah jadi akan dikumpulkan, diberi label sesuai kesepakatan akan dipamerkan dan dijual dalam pameran kampus, gereja dan pameran-pameran lainnya serta melalui media social. Peserta pelatihan yang sudah siap memasarkan prodak hasil karyanya, dipersilahkan memasarkan melalui media social masing-masing. Kegiatan ini diharapan menghasilkan berbagai jenis pengolahan sampah lainnya dan area promosi dari hasil karya peserta akan terus diperluas sampai tingkat provinsi.
\end{abstract}

\section{Kata kunci: sampah, dompet, dompet kotak susu Abstract}

One of the factors that cause environmental damage is garbage. In addition to bringing disaster to the community, garbage can also be turned into useful goods. The purpose of this activity was to increase public awareness, activity and creativity in managing waste and used goods. The training was attended by 20 participants who were Catholic women of Christ the Tenggarong. This activity was carried out eight times. Training participants are welcome to develop their ideas and creativity. The results of this activity show the creativity and enthusiasm of the trainees. The finished works will be collected, labeled according to the agreement will be exhibited and sold in campus exhibitions, churches and other exhibitions and through social media. Training participants who are ready to market their work products are welcome to market through their respective social media. This activity is expected to produce various types of other waste treatment and promotion areas from the participants' work will continue to be expanded to the provincial level.

Keywords: Garbage, wallet, milk box wallet.

\section{PENDAHULUAN}

Laju pertumbuhan penduduk di Indonesia sangat cepat dan terus meningkat. Badan Kependudukan dan Keluarga Berencana Nasional (BKKBN) memperkirakan, bila pertumbuhan penduduk tidak dikendalikan, maka prediksi jumlah penduduk Indonesia pada tahun 20502060 mencapai 450-480 juta atau dua kali lipat dari jumlah penduduk sekarang. Kenaikan jumlah penduduk tersebut jika dibandingkan dengan Negara sekitar, kita terlihat sangat besar
(Puskalitba Solo, 2018). Peningkatan jumlah penduduk tersebut dibarengi dengan banyaknya masalah yang timbul, salah satunya adalah limbah sampah yang dihasilkan setiap harinya. Kualitas lingkungan dapat menurun akibat banyaknya sampah atau bahan pencemar lain. Sampah yang dihasilkan rumah tangga seringkali tampak sedikit dan tidak dianggap mencemari lingkungan, padahal justru sampah rumah tangga yang banyak mencemari lingkungan. Beberapa akibat yang ditimbulkan oleh sampah antara lain 
pencemaran udara, air dan pencemaran tanah.

Berdasarkan sifatnya, sampah dapat digolongkan menjadi sampah anorganik dan sampah organic yaitu sampah yang mudah membusuk seperti sisa makanan, sayuran, daun-daun kering dan sebagainya. Sampah ini dapat diolah menjadi kompos. Sampah anorganik yaitu sampah yang tidak mudah membusuk, seperti plastic wadah pembungkus makanan, kertas, plastic mainan, botol dan gelas minuman, kaleng, kayu dan sebagainya. Salah satu sampah anorganik yang banyak kita jumpai disekitar kita adalah kotak susu. Susu adalah minuman penuh nutrisi yang di hasilkan dari spesies mammalia, dimana jenis susu yang biasa di konsumsi oleh manusia adalah susu sapi, susu kambing dan di beberapa belahan dunia lain ada susu unta. Karena kandungan nutrisinya yang luar biasa, maka untuk meningkatkan daya tahan dalam proses distribusinya dibuatlah susu yang di kemas dalam kemasan kotak karton. Karton sebagai kemasan biasa kita jumpai digunakan dalam produk susu kemasan dari kecil hingga besar dari berbagai merk. Setelah menikmati segala manfaat susu kita dapat menciptakan ide kerajinan tangan unik dari kotak susu bekas yang bisa di praktekan sendiri di rumah salah satunya dompet dari kotak susu yang bisa kita gunakan untuk mengurangi limbah sampah kotak susu di sekitar kita. Limbah dapat dikurangi dengan cara pemanfaatan ulang dan mendaur ulang limbah.

\section{METODE}

\section{Alat dan Bahan}

Alat dan bahan dalam kegiatan ini adalah:

Tabel 1. Alat dan bahan Pelatihan Mengolah Sampah Kotak Susu Menjadi Dompet Di Perkumpulan Wanita Katolik Kristur Raja Kecamatan Tenggarong Seberang

\begin{tabular}{lll}
\hline No & Alat dan Bahan & $\mathrm{n}$ \\
\hline 1. & Kuas 10 inci & 24 \\
2. & Gunting & 24 \\
3. & Lem putih & 24 \\
& Kain pelapis luar/motif & $50 \mathrm{~m}$ \\
& Kancing magnet & 100 \\
\hline
\end{tabular}

\section{Metode Pelaksanaan}

Kegiatan ini diawali dengan penjelasan rangkaian kegiatan dan waktu pelaksanaan yang dibutuhkan untuk pelatihan tersebut kemudian membuat kontrak waktu dan tempat yang mudah dijangkau kelompok pelatihan. Selanjutnya mempersiapkan alat dan bahan yang diperlukan dan memberikan penjelasan alat, bahan dan proses kerja kepada peserta pelatihan (mitra).

Pelatihan dimulai dengan mempraktikkan pembuatan dompet tahap demi tahap sambil diikuti peserta pelatihan dalam proses pembuatannya, mulai dari membersihkan kotak susu mengggunakan sabun atau detergen, membuat pola, menggunting pola dan bahan kain pelapis yaitu kain katun hingga pengeleman menggunakan lem putih untuk menyatukan semua bagian sampai menjadi dompet. Peserta pelatihan yang telah menguasai teknik pembuatan dipersilahkan mengembangkan ide dan kreativitasnya untuk membuat dompet yang lebih lengkap komponennya, misalnya menambahkan selipan kartu ATM, kantong penyimpanan koin, dsb.

Hasil karya yang telah jadi akan dikumpulkan, diberi label sesuai kesepakatan kelompok dan akan dipamerkan dan dijual dalam pameran kampus, gereja dan pameran-pameran lainnya serta melalui media social. 
Peserta pelatihan yang sudah siap memasarkan prodak hasil karyanya, dipersilahkan memasarkan melalui media social masing-masing. Area promosi akan terus diperluas sampai tingkat nasional.

\section{HASIL dan PEMBAHASAN}

Kegiatan ini dilakukan sebanyak delapan kali pertemuan. Pertemuan ertama menjelaskan tentang tujuan kegiatan, persiapan alat dan bahan dan penentuan waktu dan tempat kegiatan. Pertemuan selanjutnya adalah membuat dompet sampai pertemuan terakhir peserta pelatihan menghasilkan sebanyak 3 dompet yang siap dipasarkan. Kendala yang dihadapi pada kegiatan ini adalah kehadiran peserta tepat waktu yang rendah sehingga kegiatan dimulai dan diakhiri dengan jumlah peserta yang berbeda. Solusi yang diambil untuk mengatasinya adalah dengan mengelompokkan peserta menjadi 3 kelompok sesuai dengan jam kedatangan peserta pelatihan. Dompet yang dihasilkan dari pelatihan ini akan dipasarkan melalui pameran daerah bekerja sama dengan bank sampah setempat dan melalui media social secara online yang dipasarkan secara pribadi maupun kelompok.

\section{KESIMPULAN dan SARAN}

Evaluasi kegiatan yang dilakukan bersama peserta, didapatkan hasil bahwa tujuan pelatihan yang disepakati saat pertemuan pertama bersama mitra yaitu menghasilkan produk dompet minimal tiga telah tercapai dan mitra merasa pelatihan sangat berguna bagi mereka dalam menambah pengetahuan keterampilan dalam membuat dompet yang dapat digunakan sendiri, di berikan sebagai oleh-oleh dan dijual untuk mendapatkan penghasilan tambahan. Pelatihan ini akan dilanjutkan pada tahun berikutnya sesuai permintaan mitra dengan menambah kreasi model dompet yang akan dibuat.

\section{UCAPAN TERIMA KASIH}

Pelatihan ini dapat berjalan berkat dukungan dari STIKES Dirgahayu sebagai sponsor utama yang memberi dukungan penuh dalam pembiayaan kegiatan sehingga dapat terlaksana dengan baik dan memberikan manfaat yang sebesarnya bagi mitra.

\section{REFERENSI}

Aeteartesanato. 2017. Tas Sekolah dari Karton Susu. Diakses dari Pinterest

Chalik, Alex Abdi. 2011. Formulasi Kebijakan Sistem Pengolahan Sampah Perkotaan Berkelanjutan Studi Kasus DKI Jakarta. Jurnal Pemukiman, Vol. 6, April hal. 18-30 Kementrian Keuangan Republik Indonesia. 2011. Masterplan Percepatan dan Perluasan Pembangunan Ekonomi Indonesia 2011-2025. Lampiran Peraturan Presiden Republik Indonesia no. 32tahun 2011

Kusumastuti, prapti. 2014. Recycled: milk carton wallet. Agustus 20, 2014

Prajati, Gita. 2015. Pengaruh faktorfaktor ekonomi dan kependudukan terhadap timbulan sampah di ibu kota provinsi jawa dan sumatera, bandung. Jurnal teknik lingkungan vol. 21 hal. 39-47

Sembiring, E., nitivattananon, V. 2010. Sustainable solid waste management toward an inclusive society: integration of the informal sector urban managemental. School of environment, resources and development, Asian institute of technologi. Thailand journal/resources conservation and recycling 2010, hal. 802-809 
